\title{
GAMIFICATION POSSIBILITY USE FOR THE DEVELOPMENT OF POPULATION CIVIL ACTIVITY PLATFORMS
}

\author{
Olga V. Rogach ${ }^{1}$ \\ Elena V. Frolova ${ }^{2}$ \\ Tatyana M. Ryabova ${ }^{3}$ \\ Valeriy V. Bondaletov ${ }^{4}$ \\ Andrey V. Prokhorov ${ }^{5}$
}

\begin{abstract}
The authors conducted the study of electronic referendum system of the Moscow government "Active Citizen" in order to determine the possibilities of gamification use on the platforms for civil participation, the influence of game mechanics on the civic activity of Russians. The methods of research were the following ones: qualitative analysis of "Active citizen" user feedback, presented on the official Internet portal, as well as user interviews $(\mathrm{N}=30)$. The interview allowed to reveal the motivational attitudes of the
\end{abstract}

respondents' representation on the platform "Active citizen", to evaluate the key parameters of the civil activity platform functioning and the elements of gamification. The result of the study determined that the civil platform creates an opportunity to discuss some important issues for the city. However, with the observation of democratic procedure appearance, there is the substitution of real participation in the state management for the possibility of discussion. The performed study showed the ambivalent nature of gamification

${ }^{1}$ Candidate of sociological sciences, assistant professor at the Department of Management and Administration. e-mail: rogach16@mail.ru.

${ }^{2}$ Doctor of sociological sciences, professor of the Department of Management and Administration.e-mail: efrolova06@mail.ru.

${ }^{3}$ Candidate of sociological sciences, assistant professor at the Department of Management and Administration. e-mail: tani-87@inbox.ru.

${ }^{4}$ Candidate of sociological sciences, assistant professor of the Institut innovatsionnykh tekhnologiy i gosudarstvennogo upravleniya. e-mail: bondaletovvv@mail.ru.

5 Candidate of philology, associate professor at the management, marketing and advertising department; Head, The Centre of Educational Services Marketing, Derzhavin Tambov State University. e-mail: proh_and@rambler.ru. 
use. The respondents demonstrate the polarity of gaming method perception during their transfer to civil platforms: for some participants the possibility of score accumulation is a pleasant bonus to the opportunity to take part in urban problem solution, while it becomes an aim for others and an opportunity to increase one's self-esteem. According to public opinion, the system of electronic referendums of the Moscow government "Active Citizen" will not reduce the demand in the long term.

Keywords: civil activity, civil platforms, gamification, social activity, gaming techniques.

\section{Introduction}

Modern challenges and the trends of state building as a key component of public architectonics development determine the significance of civic activity development, a necessary attribute of any democratic society development (Lobna Hassan, 2017; Pogosyan, 2018).

Civic activity in the study of leading scientists is interpreted from the standpoint of a high proportion of citizens' representation provision in local community life (Adler R.P. \& Goggin J.). The purpose of such a representation is a sustainable growth of qualitative area development indicator provision (Köhler, 2013). A number of studies have noted a correlation between the increase in the civic engagement of local community representatives and the reduction of management costs (Coronado Escobar \& Vasquez Urriago, 2014); the growth of public confidence in the actions of the bureaucracy and power legitimacy (Macintosh, 2004; Bondaletov V.V. et al., 2017; Rogach O.V., et al., 2018).

A steady civic activity and citizen participation in local issue solution is a desirable practice for most developed countries (Rubinstein A.Y., 2017). The governments all over the world try to develop it, eventually arriving at very mixed results (Lee \& Kim, 2014). In terms of the technological aspect of the civic activity formation and development, a significant variety of methods and techniques to increase the citizen participation in local community life was noted (Medvedeva N.V. et al., 2017). As a rule, modern practice of civil construction includes forums and chats (Komito L., 2005); network technologies 
of social orientation (Sameer L. \& Abdelghaffar H., 2015). Game mechanics in non-gaming domains (Bista SK et al., 2014, Huotari \& Hamari, 2016) are spread everywhere, including the creation of platforms for civic participation that contribute to a two-way dialogue development between population and government (Gordon E., Walter S. \& Suarez P., 2014).

In modern conditions, the effectiveness of management is also assessed, also in terms of information and communication technology introduction practice availability in the processes of social development (Grishin A.A., Sachkov V.E. 2015; Plisova, 2017; Skorodumova O.B. \& Melikov I.M., 2017). These processes are designed to support democratic foundations and improve the quality of management decisions (SánchezNielsen D. \& Lee E., 2013). Online civil activity platforms provide the public with appropriate tools for interaction and collaboration within the local community in order to improve the quality of governance and the living standards of residents (Swezey R.M. et al., 2012). Online tools of public involvement in the life of the local community create additional advantages in the processes of civic engagement increase, enhancing the opportunities for citizen participation in governance (Phang C. W. \& Kankanhalli A., 2008).

It is fair to note that the dominance in the processes of civic activity increase in information and communication technologies is accompanied by a number of negative features that reduces their effectiveness (Gordon E., Walter S. \& Suarez P., 2014). In particular, the online platforms of civic engagement are characterized by a high turnover of users (Jin X.L. et al., 2013). Despite the worldwide growth in the number of people spending a lot of their time on the Internet, their participation in civilian activity platforms is not so high (Alharbi A., Kang K. \& Hawryszkiewycz I., 2016).

A number of current studies suggest that the use of gamification techniques on civil activity platforms will increase their attractiveness to potential "consumers» (Asquer A., 2014). This is due to the fact that games and simulators have significant advantages in terms of citizen number increase in socio-political issue resolution and, as the result, the increase 
of confidence in the actions of authorities. This assumption is based on a positive correlation between the number of active users and the number of gamification participants (Eränpalo T., 2014). It can be stated that the "design" of civic participation acquires the characteristics of gamification more and more. Gaming technology become the tool of a new form of civic engagement development, providing not just an expression of public opinion on various issues but also contributing to the training of citizens, the development of skills for real problem solution (Veltsos J.R., 2017).

At the same time, the discussion of gamification use possibilities for the development of civil activity platforms among the population is very debatable still. This is due to the lack of an unambiguous understanding of the goals to be achieved in the course of gamification, the specifics of the electronic environment, and the strategic guidelines for public administration. Modern scientific studies are dominated by the view that a full game context is not fully suitable for civic engagement platforms (Karagiorgas D.N., Niemann S., 2017), undermines the basis of population activity self-organization as a rational choice (Bondaletov V.V., 2015). The issue of the ethics is raised concerning the introduction of game mechanics in the context of nationbuilding and the provision of public services (Zuckerman O., \& Gal-Oz A., 2014).

Methodological coordinates. In order to determine the possibilities of gamification use on civic engagement platforms, the effect of game mechanics on civil activity of Russians, the authors conducted the study of the site for electronic referendums (electronic referendum system of Moscow government "Active Citizen"). In May 2018, over 2,000,000 users were registered, 3,594 votes were performed. According to their results, the Moscow authorities implemented 1,564 decisions.

The leading method of the study was the qualitative analysis of user feedback "Active citizen", presented on the official Internet portal. Besides, in order to verify the data received, the authors selected by 30 respondents who agreed to participate in the interview using the snowball method. The selection criterion was the experience of participation on the platform "Active 
citizen" for at least 6 months. The age and sex composition of the respondents is represented by the following proportions: 17 women, 13 men at the age of 18 - 47 years. 12 people were with children. The research toolkit consisted of several blocks of questions that were aimed at the revealing of the motivational attitudes of respondents' representation on the "Active citizen" platform, the evaluation of key parameters of the civil activity platform functioning and the elements of gamification.

\section{Study results}

In the course of the study, they studied the intensity of user participation in the work of civil activity platform. According to the obtained results, there is a significant variation in the frequency of user participation from 1 time per month to 1 time per day. The leading motivational attitudes of respondents' participation were the following ones: the accumulation of points, their conversion into real services and products (hoodies, mugs, event tickets, the payment of transportation services, etc.), the opportunity to vote and be

\section{5}

heard, the development of urban space development projects.

Thus, it can be concluded that the motivation of civic activity of users is based both on moral and on material values. The opportunity to realize implement their ideas for urban environment becomes particularly important. Respondents note their involvement in the processes of city management, the satisfaction with an effective feedback.

Irina K.: "An active citizen is a life stance, this is upbringing, this is an opportunity to influence the city life. It is not about just walking and swearing at the power. "Active citizen" for me is an opportunity to influence a decision, to improve. If I want to have a neat lawn next to my house, I vote for it and can really influence it."

Maxim V.: "I like the idea of the project. I'm a busy, working person can vote remotely, when it is comfortable, without any time reference. I really did not have the opportunity to express my opinion. I had my comments on various issues, and I did not know who solves them. This opportunity is given by the "Active citizen". I like most of all that my opinion is taken into account." 
http://periodicos.ufpb.br/ojs2/index.php/ged/index

At the same time, not everyone agrees with this position. Among the comments on the work of the civil platform there are the statements about an imitative nature of its work.

Alexandra Zh.: "During my time in the voting, nothing very important has been discussed. Any nonsense is suggested, for which five appraising stars will be given by the overwhelming majority of the voters. For example, everyone will support the idea of improved quality of mobile communications at thirty metro stations? And the issue of the box appearance with new candies "Moscow". Is it vitally important for someone? Is everything else in life an ideal?"

In the case of a number of users, gamification becomes an ambivalent one, the main goal of the project is eliminated, while the accumulation of points, the build-up of bonuses are brought to the fore.

Sergey Ts.: "Each of your votes you can share on the page of your VKontakt, Classmates, Facebook and Twitter account. For each social network, another 5 points are awarded. I had a long-standing account only in VK. But for the sake of a five-point supplement I appeared in the other three social networks. Once a month, you can remind that you are an "active citizen" in the same social networks by clicking on the button oa the main page "tell friends +5 points." Once a day 3 points is added for the entrance to the site, regardless of whether you present on it at the moment of voting or not. They are added for an active participation simply".

Some participants demonstrate "game addiction". The participation in voting gains the element of a game, and does not deal with the desire to solve citywide problems, to express their point of view. The participants are concentrated on point earning.

One of gamification elements is also the possibility of identification symbol obtaining, which provides a special cohesion of civil activity platform users. The respondents noted a special satisfaction from the belonging to "their" group, the opportunity to identify themselves with the most active and not indifferent part of the local community.

Daria S.: "I say: "Oh, are you the same as me? Do you participate in the project? "She smiles and says:" Yes, we are good, we help the city together." For example, sometimes $I$ walk in a 
http://periodicos.ufpb.br/ojs2/index.php/ged/index

sweatshirt "An active citizen" and people ask me: "Oh, do you have such a hoodie?" And a conversation about the project is started."

One can assume that this characteristic is more natural for the respondents who have a considerable experience and participation intensity on civic engagement platform. In particular, a number of respondents demonstrate overestimated requirements for the motivational components of gamification. There is a transfer of the gaming content to a user's real life.

Lyudmila R.: "... I would like to see more events that are difficult to get to, but they are possible with the help of the "Active Citizen". That is, it will be more exclusive events."

In contrast to these attitudes, the results of the survey also show that other respondents, with the increase of participation duration in the civil activity platform, the decrease of the project novelty degree, demonstrate the drop in interest, and the perception of the civil platform as an imitation mechanism of civil construction is developed.

Irina K.: "It will be four years soon since I was registered in the project. From the very beginning, I participated in all competitions. I used all promotional codes. But I have never been among the lucky ones, well, I'm not lucky, and that's it!"

Maria O. "The most important point! The government often manipulates us, but many do not notice it naturally. Our good ideas are appropriated by others and the common opinion of the people is positioned as a government decision ... but I am more annoyed by the fact that we do not even solve many issues in this vote, it is an illusion..."

It is fair to say that despite these negative reviews, the majority of respondents who participated in the interview support this project, noting its usefulness, informational openness and the importance in modern practice of a democratic society development.

\section{Discussion}

In the current practice of citizen participation popularization in management decision making, there are no uniform requirements for civil engineering platform development as an integral attribute of socio-political discussions and democratic discussions. However, the functions and the 
objectives of such platforms are considered in the categories of information support (the sufficiency of information on civil issues presented on the platform), interactivity (the ability to express one's position, to participate in a discussion, to interact), reflections (the mechanism for a final opinion expression, voting). These categories are developed through the simulation of a gaming context.

In gamification, users realize the need for involvement and support, they carry out communication, which is encouraged for cooperation and constructive dialogue development between government and society. At the same time, the introduction of the game element ensures the stimulation of interactivity, civic discussion and a certain kind of integration of various social groups.

Motivational opportunities of gamification ensure the desired behavior of the participants - civic engagement, the involvement in civil construction issue solution, it reduces the fluidity of users on the site for electronic referenda. The results of the study indicate the correlation between the use of adaptive opportunities for gamification and the
308

maintenance of public discussion desired level concerning the issues raised on the civil platform.

An initial prerequisite for the use of gaming techniques in non-game contexts is the reliance on getting "bonuses" and preferences from game organizers. However, a positive effect of user involvement in the discussion of management issues is temporary one, and, as a rule, it is decreased significantly, as soon as the application loses its attractiveness of novelty.

Besides, any attempt to limit the fluidity of users through the motivation via "Bonuses", "Likes" and other preferences provided by the game context, brings a number of problems, the ignoring of which leads to the undermining of the democratic foundations of a state.

Gamification does not bring anything wrong, but researchers in the field of psychology point out that a man is inherently inclined to some degree of dependence. In the extreme form of its manifestation, a complete destruction of social life takes place, the interest in the world disappears. Substituting real life with a virtual reality, a person stops growing spiritually. There is a real 
replacement of true achievements with virtual symbols, a false image of oneself and personal significance. The following fact is interesting: the people with low culture, an inadequate financial support, mentally retarded people are prone to gaming addiction most of all. Proceeding from mentioned above, the following question arises: What are the results of gamification introduction in the processes of activity stimulation on civil platforms? A civil platform creates an opportunity to discuss important issues for a city. The possibility of issue discussion is not the participation in the decision on these issues. Observing the appearance of democratic procedures, there is the substitution of real participation in the government for the possibility of discussion in fact. Understanding of such a dialogue futility leads to "the washing away" of an interested and sensible majority from the platform and its "flooding" with a dubious minority of gamers and the collectors of "points" and "likes". Thus, the violation of the democratic principle of minority subordination to the majority and the establishment of statism in public relations take place.
Therefore, the introduction of gamification in the processes of civic activity stimulation is not unambiguous, which requires a more thorough study of its psychological nature and possible consequences.

However, according to public opinion estimation, the system of electronic referendums of the Moscow government "Active Citizen" will not reduce its relevance in the long term.

\section{Conclusion}

In modern conditions of a democratic society development, researchers focus on the development of tools for population civic engagement development, increasing the increase of the number of citizens focused on a constructive dialogue with the authorities. This circumstance, on the one hand, is designed to increase the openness of management decisions, to increase the legitimacy of the government and improve its image in the eyes of the general public (Frolova E.V. et al., 2017), while on the other hand it is limited by the difficulty of gamification design transfer to public services, the discussion nature of such a format of 
civil participation concerning key sociopolitical issues.

The government initiative on the introduction of gamification in the processes of civil activity stimulation is based on the conversion possibility of the internal bonuses of users into real rewards. The study showed the ambivalent nature of gamification use. Respondents demonstrate the polarity of gaming method perception during their transfer to civil platforms: for some participants the possibility of point accumulation is a pleasant bonus to the opportunity of taking part in urban problem solution, while for others it becomes an end in itself and an opportunity to increase one's selfesteem.

The desire of participants to identify themselves is noted, to identify themselves with a special status group of active, not indifferent citizens. These respondents are characterized by excessive requirements to the bonus system of the civil platform and the desire to receive exclusive services.

The majority of respondents noted the effectiveness of the "Active citizen" platform, a special role of gamification in civil activity development.

\section{References}

Adler R.P. \& Goggin J. (2005) What do we mean by "civic engagement." Journal of Transformative Education, 3(3), 236253.

Alharbi, A., Kang, K., \& Hawryszkiewycz, I. (2016). The influence of trust and subjective norms on citizens intentions to engage in Eparticipation on E-government Websites. arXiv preprint arXiv:1606.00746.

Asquer, A. (2014). Not just videogames: Gamification and its potential application to public services. In Digital public administration and E-government in developing nations: Policy and practice, edited by E. F. Halpin. IGI Global, in press.

Bista S.K., Nepal S., Paris C. \& Colineau N. (2014). Gamification for online communities: A case study for delivering government services. International 
Journal of Cooperative Information Systems, 23, 1441002.

Bondaletov, V.V. (2015) Evolution of self-organization ideas. // Sotsiologicheskie Issledovaniya. January (3), S. 132-139.

Bondaletov, V.V. et al. (2017) Public evaluation of police activities. // Sotsiologicheskie Issledovaniya. № 4, S. $52-59$

Coronado Escobar, J. E., \& Vasquez Urriago, A. R. (2014, October). Gamification: An effective mechanism to promote civic engagement and generate trust? In Proceedings of the 8th International Conference on Theory and Practice of Electronic Governance (pp. 514-515). Guimaraes, Portugal: ACM.

Eränpalo, T. (2014). Exploring young people's civic identities through gamification: A case study of Finnish, Swedish and Norwegian adolescents playing a social simulation game. Citizenship, Social \& Economics Education, 13(2), 104-120.
Frolova E.V., Ryabova T.M., Rogach O.V. Bureaucrat image in Russia. Journal of Advanced Research in Law and Economics Volume VIII, Issue 3(25), Summer 2017, pp.52-59

Gordon E., Walter S. \& Suarez P. (2014). Engagement games: A case for designing games to facilitate real-world action. Boston, MA: EGL. Retrieved from http://engagementgamelab .org/pdfs/engagement-gameguide.pd

Grishin A.A., Sachkov V.E. (2015) Introduction psycho social network analysis. Herald of MSTU MIREA, №4 (9) Vol 1. ( December 2015, Issue 9 ) pp.198-205.

Huotari, K., \& Hamari, J. (2016). A definition for gamification: Anchoring gamification in the service marketing literature. Electronic Markets, 1-11.

Jin, X. L., Zhou, Z., Lee, M. K., \& Cheung, C. M. (2013). Why users keep answering questions in online question answering communities: A theoretical and empirical investigation. International Journal of Information Management, 33(1), 93-104. 
Karagiorgas D.N., Niemann S. (2017)

Gamification and Game-Based Learning Journal of Educational Technology Systems Vol 45, Issue 4, pp. 499 - 519 https://doi.org/10.1177/0047239516665 $\underline{105}$

Komito, L. (2005). e-Participation and governance: Widening the net. The Electronic Journal of e-Government, 3(1), 39-48.

Köhler J. (2013) Globalization and Sustainable Development: Case Study on International Transport and Sustainable Development. The Journal of Environment \& Development. Vol 23, Issue 1, pp. $66 \quad-100$ https://doi.org/10.1177/1070496513507 $\underline{260}$

Lee J. \& Kim S. (2014, January). Active citizen e-participation in local governance: Do individual social capital and e-participation management matter? In 2014 47th Hawaii International Conference on System Sciences (HICSS) (pp. 2044-2053). Hawaii, USA: IEEE.
Lobna Hassan. Governments Should Play Games: Towards a Framework for the Gamification of Civic Engagement Platforms. Simulation \& Gaming 2017, Vol. 48(2) 249 -267. DOI: $10.1177 / 1046878116683581$

Medvedeva N.V., Rogach O.V., Ryabova T.M., Frolova E.V. Analysis of institutional limitations of forming and developing social partnership in the modern Russia. Espacios. 2017. T. 38. № 49. C. 4.

Phang, C. W., \& Kankanhalli, A. (2008). A framework of ICT exploitation for eparticipation initiatives. Communications of the ACM, 51(12), 128-132.

Plisova A.A. (2017) The Organization of Information Interaction with the Students Within the Educational Environment of the University. Scientific notes of the Russian State Social University. T. 16 No 6 (145). P. 124-131

Pogosyan V.G. (2018) Self-Organization of the Social System: Basic Methodological Approaches. Social 
Policy and Sociology. T. 17. № 1 (126).

P. 77-84.

Rogach O.V., Ryabova T.M., Frolova E.V., Evstratova T.A., Kozyrev M.S. Social and psychological climate in state authorities. Espacios. 2018. T. 39. № 11. C. 19-28.

Rubinstein A. Y. Elements of the general theory of the mixed economy defects. Public Administration Issues, no 1, pp. $71-102$

Sameer L. \& Abdelghaffar H. (2015, June). The use of social networks in enhancing e-rulemaking. Proceedings of the 15th European Conference on EGovernment. Portsmouth, UK.

Sánchez-Nielsen, E., \& Lee, D. (2013, January). eParticipation in practice in Europe: The case of "puzzled by policy: Helping you be part of EU." In 2013 46th Hawaii International Conference on System Sciences (HICSS) (pp. 18701879). Hawaii, USA: IEEE.

Skorodumova O.B., Melikov I.M. New Trends in Social Management of
Information Society. T. 16 No 6 (125). P. $150-156$

Swezey, R. M., Sano, H., Hirata, N., Shiramatsu, S., Ozono, T., \& Shintani, T. (2012, August). An e-participation support system for regional communities based on linked open data, classification and clustering. In 2012 IEEE 11th International Conference on Cognitive Informatics \& Cognitive Computing (ICCI* CC) (pp. 211-218). Kyoto, Japan: IEEE.

Veltsos J. R. (2017) Gamification in the Business Communication Course Business and Professional Communication Quarterly Vol 80, Issue 2, $\quad$ pp. $194 \quad$ - 216 https://doi.org/10.1177/2329490616676 $\underline{576}$

Zuckerman, O., \& Gal-Oz, A. (2014). Deconstructing gamification: Evaluating the effectiveness of continuous measurement, virtual rewards, and social comparison for promoting physical activity. Personal and Ubiquitous Computing, 18(7), 1705-1719 